\title{
ALOBIELLOPSIS R.M. SCHUST. (HEPATICAE) - A GENUS NEW FOR RUSSIA, DISCOVERED IN THE KURIL ISLANDS (NORTH-WEST PACIFIC)
}

\section{ALOBIELLOPSIS R.M. SCHUST. (HEPATICAE) - НОВЫЙ ДЛЯ РОССИИ РОД, НАЙДЕН НА КУРИЛЬСКИХ ОСТРОВАХ (СЕВЕРО-ЗАПАДНАЯ ПАЦИФИКА)}

\author{
VADIM A. BAKALIN ${ }^{1}$ \\ ВАДИМ АНДРЕЕВИЧ БАКАЛИН ${ }^{1}$
}

Abstract

Alobiellopsis R.M. Schust., based on an identification of Alobiellopsis parvifolia (Steph.) R.M. Schust, is a new for Russian liverwort flora genus recently discovered on Iturup Island (southern Kurils, Northwest Pacific). The description of its morphology and ecology as well as illustrations of the species are provided.

Резюме

На основании определения Alobiellopsis parvifolia (Steph.) R.M. Schust., найденного на о-ве Итуруп (Южные Курилы, северо-западная Пацифика), впервые для России указывается род Alobiellopsis R.M. Schust. Приводится описание морфологии и экологии, а также иллюстрации вида.

During the expedition to Iturup Island (Southern Kurils, Northwest Pacific Ocean), the author collected plants characterized by unlobed leaves, absence of trigones in leaf cells, pellucid, thin-walled and enlarged stem cortical cells and minute underleaves. A careful examination revealed that this sample belongs to Alobiellopsis parvifolia (Steph.) R.M. Schust., being the first record of this species in Russia (Iturup Island, Gniloye Lake Area, 4508'33" N, 147 57'26" E, 422 m alt., 14.IX.2005, V. Bakalin, VLA).

The original description of Alobiellopsis is brief and includes only Latin diagnosis (Schuster, 1965), while later Schuster (1969) discussed this genus in detail. In the latter paper, the genus was placed in a newly described subfamily Alobielloideae R.M. Schust. of Cephaloziaceae. In addition to Alobiellopsis, Schuster included in this subfamily also the genera Alobiella (Spruce) Schiffn. and Iwatsukia Kitagawa. Schuster (2002: $51)$ noted that "the group has an enigmatic distribution: Iwatsukia is neotropical (2 spp.) + disjunct Old World and Alobiellopsis (5 spp.) has two neotropical taxa, one in Japan, two in S. Africa. Alobiella (2 spp.) <..> Although derivative in most ways the group, today with relict range, seems to have an old, perhaps early Cretaceous distribution".

Within the subfamily Alobielloideae, the genus Alobiellopsis is characterized, accordong to Schuster (1969) by: (1) unlobed leaves (versus bilobed or unlobed in Alobiella); (2) occasional presence of reduced or vestigial underleaves (versus underleaves clearly bilobed or bidenticulate); (3) occasional presence of secondary pigmentation (versus its absence); (4) presence of gemmae (versus their absence); (5) perianths that are developed on leafy branches of normal size (versus perianths that always or most often are developed on very short ventral-intercalary branches); (6) more or less smooth cuticle (versus minutely to moderately papillate to papillose-striolate).

The following description is based on material from the Iturup Island, supplemented by data of Schuster (1969) that are given in square brackets.

1 - Institute of Biology and Soil Science, 100-Letiya Vladivostoka Street, 159, Vladivostok, 690022, Russia, v_bak@list.ru. 


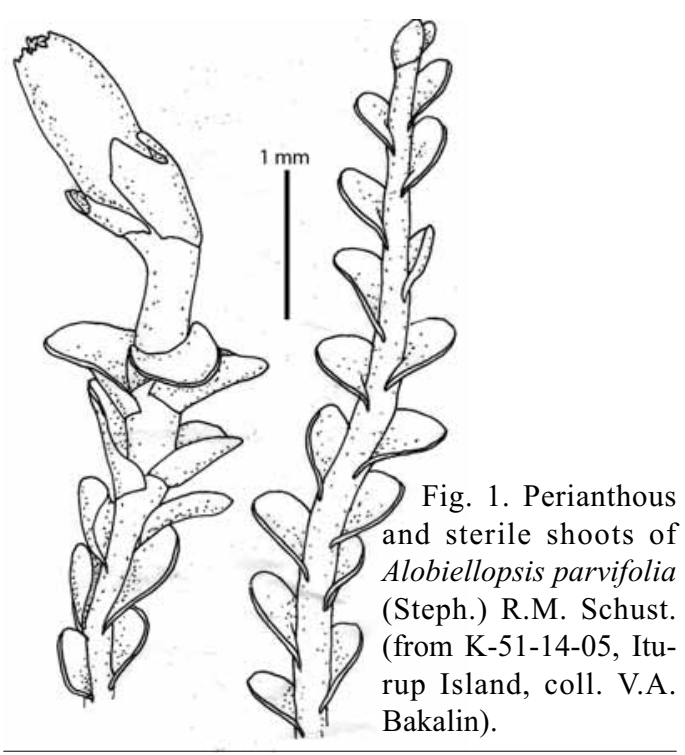

Alobiellopsis parvifolia (Steph.) R.M. Schust., Bull Nat. Sci. Museum, 1969, 12(3): 679. - Alobiella parvifolia Steph., Spec. Hep. 1908, 3: 32.

Figs. $1 \& 2$

Plants more or less hyaline, soft-textured, leaf shoots about 0.4-0.5 mm wide, 3-5 mm long, whitish to brownish, prostrate or rarely ascending, branches are postical-intercalary. Stem in crosssection elliptical (160-200 x 100-120 $\mu \mathrm{m})$, with 12 outer cells and 15 inner cells; outer cells pellucid, 30-60 $\mu \mathrm{m}$ in diameter, larger than inner cells. Rhizoids freely produced, scattered, colorless, and most frequently on the underleaf bases. Leaves ovate, suborbicular to subquadrate, 250$300 \mu \mathrm{m}$ long, 290-350 $\mu \mathrm{m}$ wide, unlobed, with entire margin, inserted obliquely to subhorizontally. Underleaves minute [to large] and often reduced to slime papillae on weak stems; leaf cells delicate, pellucid, smooth, 60-70 x 25-35 $\mu \mathrm{m}$; marginal cells usually transversely elongate, $50-60 \mathrm{x}$ 35-45 $\mu \mathrm{m}$. Leaf cells with 2-4 botryoidal oil-bodies per cell. Dioicous. [Androecia often elongate, with numerous, unlobed, slightly reduced bracts, bracts unlobed]. Gynoecia acrogynous on leading axes, with bilobate bracts slightly larger than leaves. Perianth with mouth open, truncate or dentate, bistratose basally. [The seta in cross-section with 8 outer and 4 inner cells, 200-220 $\mu \mathrm{m}$ in diameter. The capsule ovoid-ellipsoidal, dark purplish.].

The Kuril Islands materials differ from the description of $A$. parvifolia published by Schuster (1969) by: 1) minute to vestigal underleaves, sometimes reduced to slime-papillae or totally absent, and 2) dentate perianth mouth. I studied specimens published in Exsiccatae Bryophytes of Asia (fasc. 8., 2001, N. 191, 9.XI.2001, coll. M. Itouga) where only perianthous plants have more or less distinct underleaves, while sterile plants have only vestigial underleaves. In this specimen, however, plants have only truncate perianth's mouth. It seems that $A$. parvifolia varies in some features more extensively than it is described in Schuster (1969).

Alobiellopsis parvifolia occurs from middle to southern Japan, in Honshu, Shikoku, Kyushu, and Ryukyu (Yamada \& Iwatsuki, 2006) and it is the only species found in Eurasia. Two other species are known in South America and two more (with unclear systematic positions) are described from Africa (Schuster, 1969). The most common habitats of the species are wet rocks and fine-grained soil along creeks in mountainous area (most frequently in broad-leaved and coniferous forests). On Iturup Island, this species was collected on fine-grained soil in a ruts of a country road in the large hummock' Carex-Juncus-moss bog surrounded by a Betula ermanii Cham. and Pinus pumila (Pall.) Regel community. This habitat type is fairly unusual for the species. It is probable, therefore, that the occurrence of $A$. parvifolia on the island is a result of an accidental introduction. This hypothesis, however, requires further study.

Alobiellopsis is the only species of Cephaloziaceae with unlobed leaves found in Russian flora. In the regional flora of the Russian Far East, the sterile plants of $A$. parvifolia is hard (but possible) to confuse with Solenostoma koreanum Steph. or S. fusiforme (Steph.) Amakawa. From the both these taxa A. parvifolia differs by the at least occasional presence of underleaves and the large hyaline outer cells of stem.

Fig. 2. Alobiellopsis parvifolia (Steph.) R.M. Schust. (from K-51-14-05, Iturup Island, coll. V.A. Bakalin): 1 - perianthous shoot; 2 - sterile shoots; 3 - apex of sterile shoot; 4 - bracts; $5-7$ - leaves; 8 perianth's mouth; 9 - ventral side of stem; 10 - dorsal side of stem; 11 - stem's cross section; 12 - perianth; 13 - basal part of perianth; 14 - middle part of the perianth, 15 - upper part of perianth; 16 - amphigastrium. 

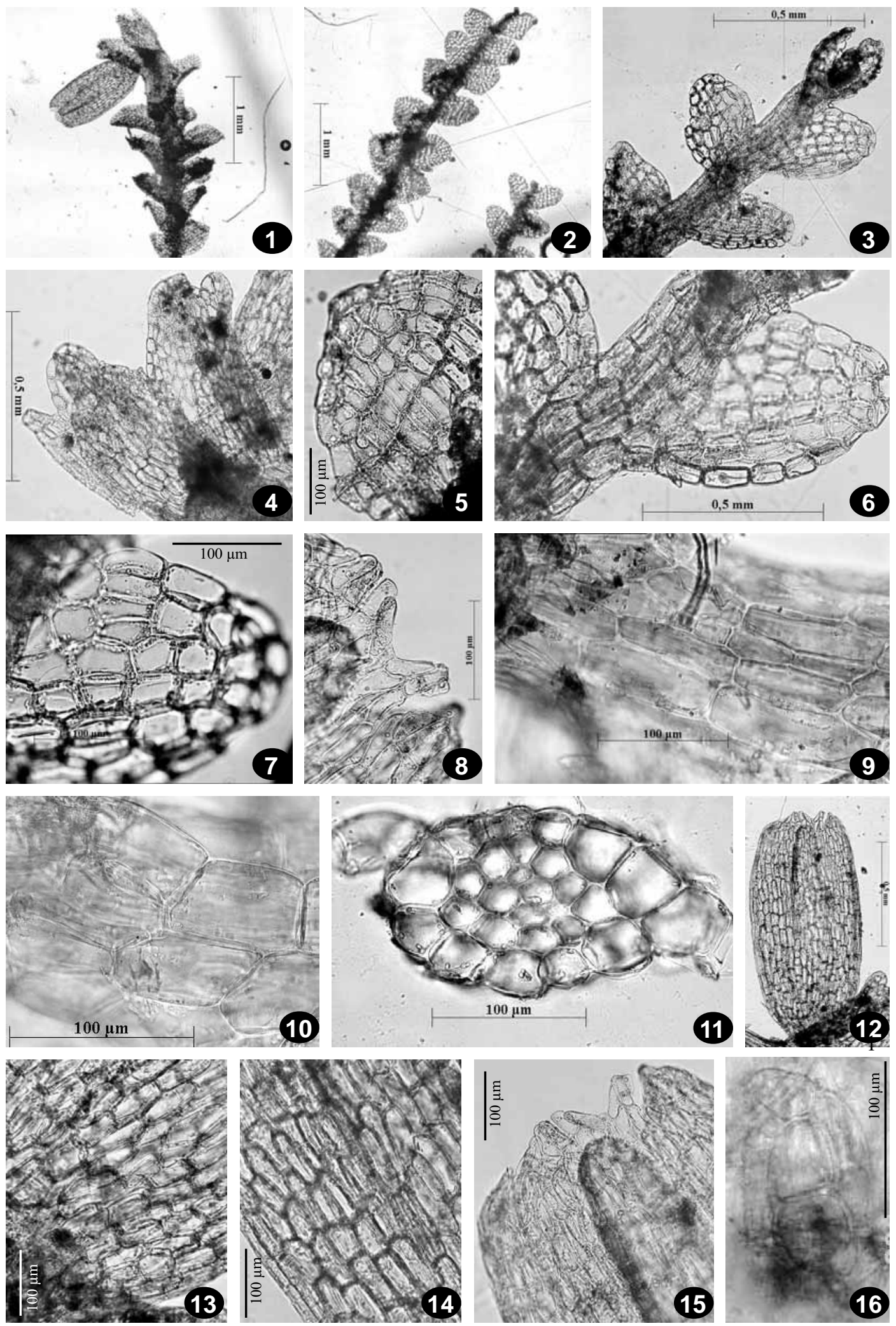


\section{ACKNOWLEDGEMENTS}

Author thanks Mr. Misha Jones for editing the English version of this manuscript and Dr. N.A. Konstantinova (KPABG) for the loan of specimen A. parvifolia. This work was partial- ly supported by grants provided by the RFBR (№ 06-05-64137), Far Eastern Division of RAS (№№ 06-III-A-06-153, 06-III-B-06-190, 07-IIID-06-044) and by the Russian Science Support Foundation.

\section{LITERATURE CITED}

SCHUSTER, R.M. 1965. Studies on Hepaticae. XXVI. The Bonneria-Paracromastigum-Pseudocephalozia-Hyalolepidozia-Zoopsis-Pteropsiella complex and its allies: a phylogenetic study. - Nova Hedwigia 10(1-2): 19-61.

SCHUSTER, R.M. 1969. Studies on Hepasticae XLVI-XLVII. On Alobiella (Spr.) Schiffn amd Alobiellopsis Schust. -
Bull. National Science Museum 12(3): 659-683.

SCHUSTER, R.M. 2002. Austral Hepaticae. Part II. - Nova Hedwigia Beih. 119: viii +606.

YAMADA, K. \& Z. IWATSUKI 2006. Catalog of the hepatics of Japan. - J. Hattori Bot. Lab. 99: 1-106. 